\title{
The FPS/WWF Revolving Fund
}

The Revolving Fund for urgent conservation projects was set up by the FPS with an initial grant of 65000 ; the repayment of 50 per cent of the grants was to be a first call on WWF's uncommitted funds. Its value lies mainly in the speedy response that can be given to urgent appeals for comparatively small sums which may make all the difference between getting a project started in time and missing the bus altogether by being too late. We are very grateful for any gifts to the Fund, whether earmarked for particular projects or not.

At its April meeting the FPS Council made a number of grants from the FPS/WWF Revolving Fund. These were $£ \mathrm{I} 700$ for the kouprey in Cambodia; $£_{1000}$ for the Somali wild ass survey in Ethiopia; $£ 3000$ for the Abuko reserve in The Gambia; 6995 for the mountain gorilla in Rwanda; and $£ 500$ each for the Jamaican hutia survey and for South African sea birds, including the jackass penguin.

\section{The Kouprey}

This giant forest ox of Cambodia, first described as recently as 1957, is in as serious danger as any animal in the world. Dr Pierre Pfeffer, who has visited the kouprey reserves three times, the last in the summer of 1969 , believes that numbers are down to about 23 in the reserve on the Vietnam frontier, 40 in the one on the Thai and Laos frontier, and a few possibly in a third reserve. With numbers like these their situation in a war zone is clearly perilous indeed, and the reserves, created by the Cambodian government for the kouprey, are clearly no sanctuary today. Dr Pfeffer believes that the only hope of saving the kouprey lies in Dr Coolidge's suggestion of a capture programme to start a captive breeding unit, first in a safe place in Cambodia, and later a second one overseas. The Cambodian government has approved the project, and Dr Pfeffer, working in collaboration with the Ministry of Agriculture, the Service des Eaux et Forêts and the FAO representative in Cambodia, is prepared to try at the first favourable moment. IUCN sent an urgent appeal for $£ 1700$ so that $\mathrm{Dr}$ Pfeffer could go the moment it was possible, but the American military invasion of Cambodia immensely complicated the operation. Since the grant was made two generous benefactors, Lord Dulverton and Colonel Ian Grant, have each given $f 800$ to the Fund for the kouprey project, and we are immensely grateful to them.

\section{Somali Wild Ass}

The largest surviving population of the Somali wild ass is believed to be one of not more than 250 animals in the Sardo-Tendaho area of Danakil, in Ethiopia, and a thorough survey is needed of the animal's status, habits and requirements before conservation management plans can be made. Dr Hans Klingel has agreed to do the survey, and the Zoological Society of Frankfurt has matched the Revolving Fund contribution of $f 1000$ with another. WWF is contributing the balance. 


\section{Abuko Came Reserve}

A description of this small new game reserve in The Gambia, to which the Fund has given $£ 3000$ for fencing, is in an article by Sir Landsborough Thomson, who visited The Gambia and reported on the reserve in January this year (page 293). This is The Gambia's first wildlife reserve, and by helping it to get going the FPS hopes to arouse interest in wildlife conservation in this small, newly independent country.

\section{Rwanda Mountain Gorillas}

Everyone who has recently visited the Rwanda mountain gorilla areas in the Mt Visoke volcano pays tribute to the splendid protective part that Miss Dian Fossey has played there. While studying the gorillas she has also kept cattle and people away from them, destroyed snares, and generally acted as a (very fierce) watchdog. (See the article on page 256 of the May ORYX). But Miss Fossey has to spend some months in Cambridge and has requested that another scientist, Alan Goodall, should be installed in her camp to continue her watchdog activities while studying the gorillas; the grant is a contribution to this.

\section{Jamaican Hutia}

Little is known about this endangered rodent - photographs of the very similar Bahaman hutia appeared in ORYX, September I969-and Professor Goodbody of the University of the West Indies is prepared to supervise two students in a survey to collect all possible data about the populations.

\section{South African Seabirds}

The recently formed South African National Foundation for the Conservation of Seabirds (Sancob) is concerned especially about the greatly decreased numbers of the jackass penguin and the need for basic biological research on this species, and also the need for a rescue station which would provide research facilities for rescuing oiled birds - a serious problem off the South African coast, as the Esso Essen disaster showed; over 1700 oiled penguins and many other birds were picked up on that occasion.

\section{Other Grants}

In addition to the grants from the Revolving Fund, FPS has given a small gift of $f_{\text {IOO }}$ to a project of the Kenya Ministry of Tourism and Wildlife for fencing the Saiwa swamp, at Kitale, the only certain habitat in Kenya of sitatunga, the swamp-loving antelope; and $£_{3} 300$ to Keith Corbett for his conservation work and study of the sand lizard in Britain about which he wrote in ORYX, September 1969.

Reports from Hawaii are that the nene goose, on the verge of extinction twenty years ago, is today spreading its range on the islands of Hawaii and Maui, thanks to breeding programmes which built up stocks in captivity which were then released on the islands. 


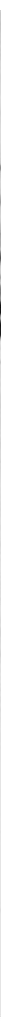

Plate 1

FOR CONSERVATION IN PAKISTAN. Fred Koning, who drove this Landrover from London to Karachi, presents the keys to Syed Baba Ali, of the Pakistan Appeal of the World Wildlife Fund. The Landrover was given through the FPS/WWF Revolving Fund, thanks to a generous anonymous gift of $£ 1000$ to the FPS. The vehicle was urgently needed for the immediate use of Major lan Grimwood, who is assisting the Pakistan Government in the setting up of wildlife reserves-see the Note on page 286. Fred Koning's long journey proved particularly rewarding as he was able to report the sighting, on a lake in Afghanistan, of 75 Siberian cranes. This was the first record of this rare and endangered 'Red Book' species outside the the USSR for 35 years, apart from those that visit Bharatpur, near Delhi, each winter. C. D. Savage 


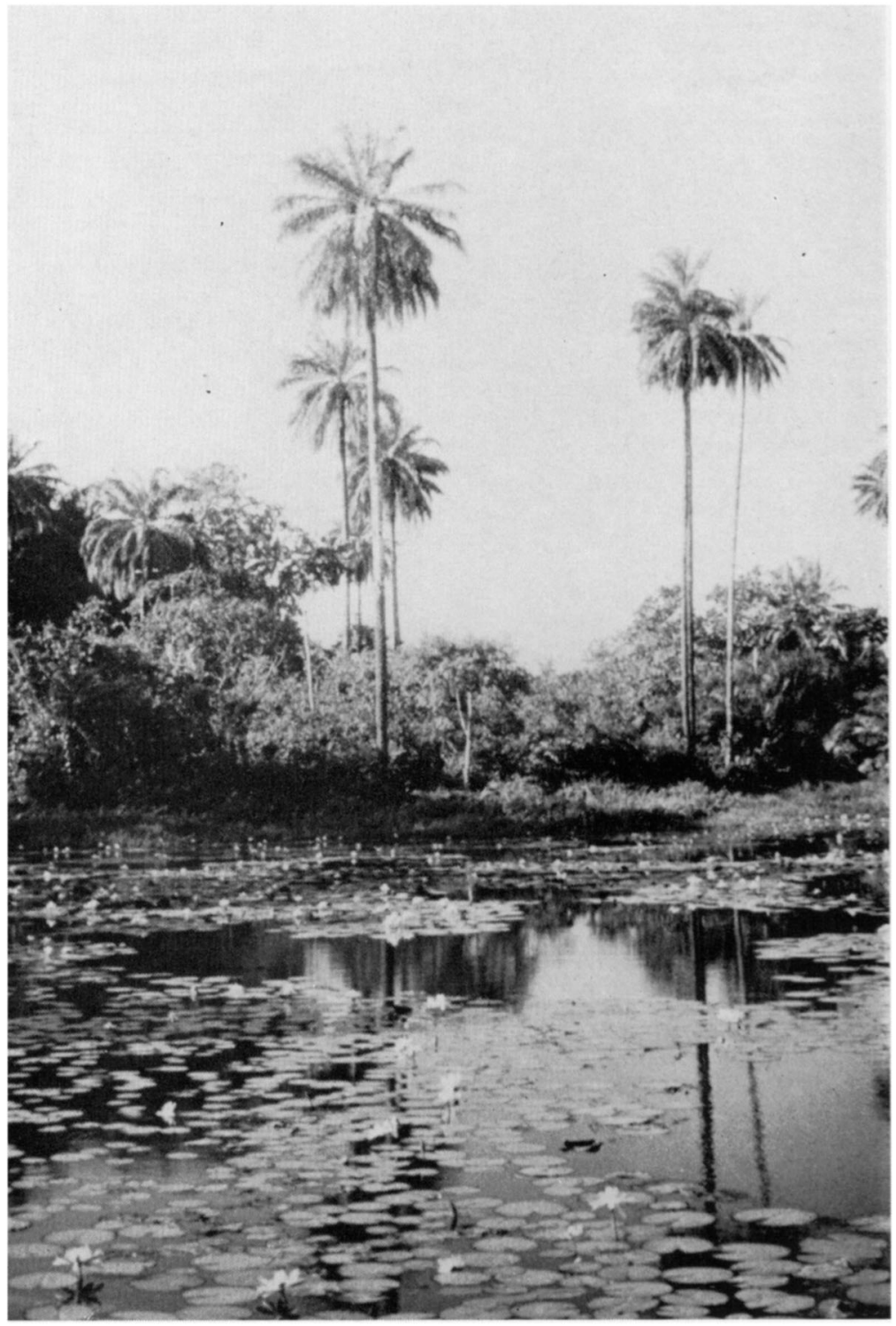

Plate 2

THE ABUKO RESERVE. A view in the new Abuko

Nature Reserve in the Gambia.

Sir Landsborough Thomson 